\title{
Structure Analysis of Reinforced Concrete Shaft-Well Inverted Siphon
}

\author{
Xie Xiangzan \\ Hunan Urban Construction College \\ Xiangtan, China \\ e-mail: 42831966@qq.com
}

\begin{abstract}
Tieluqiao inverted siphon project is located on the main canal of Songshu reservoirs in Liaoning province, pipeline through north hole of changchun-dalian railway bridge, with the railway bridge orthogonal. The inverted siphon is thin-walled concrete structure, Sstructural analysis is of great significance to study the safety the inverted siphon, through static analysis, can get the change law of stress and displacement of the inverted siphon. The stress and strain of inverted siphon structure not only are the index of inverted siphon structure rigidity, but also are the basis of identifying whether the inverted siphon structural damage occur. Shaft-Well inverted siphon structure is novel, and loading is complex, this paper has carried on structure analysis of this kind inverted siphon project, and analyse mechanical characteristics of inverted siphon structure during construction and operation period, can provides a certain reference basis for design and construction of inverted siphon.
\end{abstract}

Keywords-Shaft-well; Inverted siphon; Structure analysis; Operation period; Stress distribution.

\section{INTRODUCTION}

Tieluqiao inverted siphon project is located on the main canal of Songshu reservoirs in Liaoning province, pipeline through north hole of changchun-dalian railway bridge, with the railway bridge orthogonal, import and export is reinforced concrete shaft-well and connects stone arch aqueduct[1]. Inverted siphon project's design flow is $8 \mathrm{~m} 3 / \mathrm{s}$, design head is $10.6 \mathrm{~m}$, the biggest head is $12.5 \mathrm{~m}$, head loss is $0.4 \mathrm{~m}$, velocity is $1.51 \mathrm{~m} / \mathrm{s}$. Inverted siphon's inner diameter is $2.6 \mathrm{~m}$, wall thickness is 0.22 $\mathrm{m}$, roughness is 0.017 , total length of inverted siphon is $83.80 \mathrm{~m}$. Concrete strength grade of inverted siphon pipe is $\mathrm{C} 20$, all pipe has three expansion joints[2].

\section{STRUCTURE ANALYSIS}

\section{A Material Parameters.}

Concrete strength grade of inverted siphon pipe is C20, elastic modulus of concrete is $25.5 \mathrm{GPa}$, poisson's ratio of concrete is 0.167 , bulk density is $24 \mathrm{kN} / \mathrm{m} 3$. At the bottom of the concrete with the cushion layer, concrete strength grade of cushion layer is C15, elastic modulus of concrete is $22 \mathrm{GPa}$, poisson's ratio of concrete is $0.167[3]$. Concrete strength grade of reinforced is II, elastic modulus of concrete is $200 \mathrm{GPa}$, poisson's ratio of concrete is 0.28 [4-5].

\section{B Element Division.}

When establishing structural finite element calculation model for inverted siphon pipe, we uses eight node isoparametric brick element to simulate inverted siphon, and each node has three translational degrees of freedom, this elment is often applied in analysis of three-dimensional entity structure mode[6-7]. The calculation model simulate the whole of the inverted siphon from import to export, length of model is $55 \mathrm{~m}$, height of reinforced shaft-well is $14.4 \mathrm{~m}$, thickness of cushion is $0.6 \mathrm{~m}[8-9]$. Element division of inverted siphon shows in Fig.1.

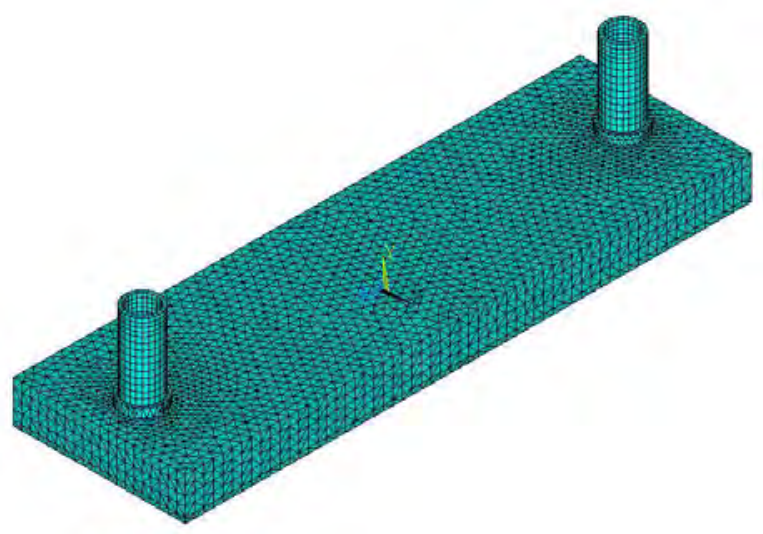

Figure 1. Element division of shaft-well inverted siphon

\section{Calculation Cases.}

According to mechanical characteristics of the railway bridge inverted siphon project during construction and operation period, structural analysis mainly considers three kinds cases[10]: case 1, dead weight of inverted siphon (construction case); case 2, dead weight and minimum head $10.6 \mathrm{~m}$ (operation case); 
case 3, dead weight and design head $12.5 \mathrm{~m}$ (operation case).

\section{ANALYSIS OF CALCULATION RESULTS}

\section{A Path of Analysis.}

Now from the middle section of inverted siphon, selects a key point every $4 \mathrm{~m}$, along the flow direction in the inverted siphon inner surface determine the three paths, in order to analyse stress and deformation of inverted siphon. Path 1, top of inverted siphon; path 2, waist of inverted siphon; path 3 , bottom of inverted siphon.

\section{B Stress Analysis}

Table 1. shows circumferential stress of each key point for inverted siphon's analysis path under various cases.

TABLE I. CIRCUMFERENTIAL STRESS OF EACH KEY POINT FOR ANALYSIS PATH UNDER VARIOUS CASES (MPA)

\begin{tabular}{|c|c|c|c|c|c|c|c|c|c|}
\hline \multicolumn{2}{|c|}{ Key point } & 1 & $(2)$ & $(3)$ & 4 & 5 & 6 & 7 & 8 \\
\hline \multirow{4}{*}{ Case 1 } & Path 1 & 0.098 & 0.100 & 0.099 & 0.097 & 0.094 & 0.096 & 0.093 & 0.229 \\
\cline { 2 - 10 } & Path 2 & -0.148 & -0.152 & -0.149 & -0.148 & -0.149 & -0.143 & -0.212 & -0.446 \\
\cline { 2 - 10 } & Path 3 & 0.101 & 0.098 & 0.101 & 0.096 & 0.099 & 0.094 & 0.094 & 0.092 \\
\hline \multirow{4}{*}{ Case 2 } & Path 1 & 0.809 & 0.808 & 0.805 & 0.805 & 0.793 & 0.793 & 0.803 & 1.273 \\
\cline { 2 - 10 } & Path 2 & 0.355 & 0.350 & 0.354 & 0.355 & 0.357 & 0.383 & 0.253 & 0.614 \\
\cline { 2 - 10 } & Path 3 & 0.899 & 0.885 & 0.894 & 0.891 & 0.890 & 0.882 & 0.887 & 0.744 \\
\hline \multirow{3}{*}{ Case 3 } & Path 1 & 0.923 & 0.922 & 0.918 & 0.919 & 0.906 & 0.909 & 0.938 & 1.468 \\
\cline { 2 - 10 } & Path 2 & 0.474 & 0.470 & 0.474 & 0.474 & 0.477 & 0.500 & 0.346 & 0.734 \\
\cline { 2 - 9 } & Path 3 & 1.016 & 1.000 & 1.010 & 1.008 & 1.006 & 1.000 & 1.014 & 0.854 \\
\hline
\end{tabular}

As can be seen from table 1, under case 1 , circumferential stress of inverted siphon is small, circumferential stress on the path 2 is compressive stress, this is mainly due to the under the action of gravity, inverted siphon is compressed at waist, and is tensed at top and bottom, so circumferential stress on the path 1 and 3 is hoop tensile stress, circumferential stress on the path 2 is hoop compressive stress. Under case 2 and 3 , circumferential stress of inverted siphon is tensile stress, and increases with the increase of water level. Circumferential stress of key point 8 under various cases is large, this is mainly due to key point 8 is at the Ig. 2 and Fig. 3 .

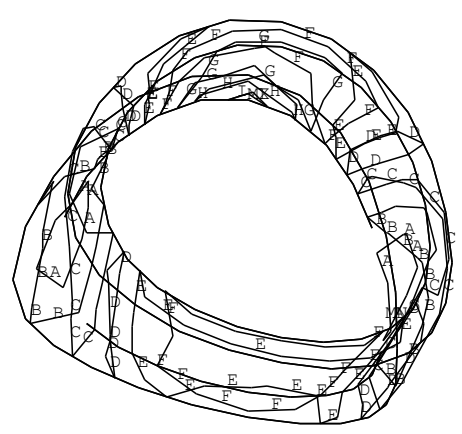

Figure 2. Circumferential stress contour map of inverted siphon under case $3(\mathrm{~Pa})$

As can be seen from Fig .2 and Fig .3, circumferential stress and axial stress contour map at the junction of

junction of inverted siphon and shaft-well and produce stress concentration phenomenon which leads to the circumferential stress value slightly. Under various cases, circumferential stress of inverted siphon at top and bottom is larger than circumferential stress of inverted siphon at waist, this is mainly due to the effects of dead weight.

As a result of at the junction of inverted siphon and shaft-well circumferential stress is large, we give circumferential stress and axial stress contour map at the junction of inverted siphon and shaft-well under case 3, as shown in $\mathrm{F}$

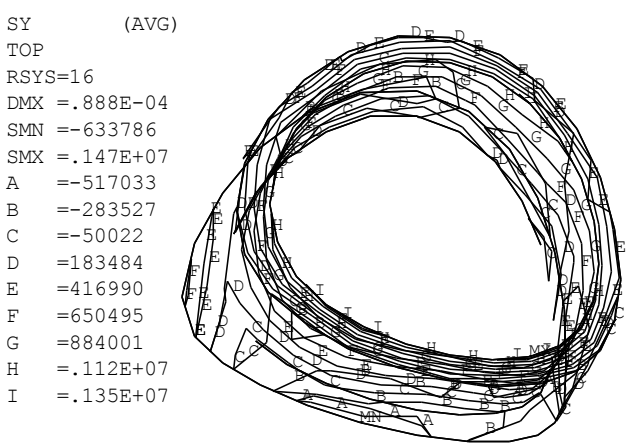

Figure 3. Axial stress contour map of inverted siphon under case 3 $(\mathrm{Pa})$

inverted siphon and shaft-well is large, distribution is more complicated. Especially at the top of inverted siphon, its largest hoop tensile stress has reached 1.35 
$\mathrm{MPa}$, which is mainly caused by stress concentration phenomenon on the border. But the axial stress value of the inverted siphon is much less than the circumferential stress value, the maximum axial stress values is only $0.201 \mathrm{MPa}$.

\section{Deformation Analysis.}

Because case 3 is design case, and under case 3 water pressure is largest, we give total displacement nephogram of inverted siphon, as shown in Fig .4.

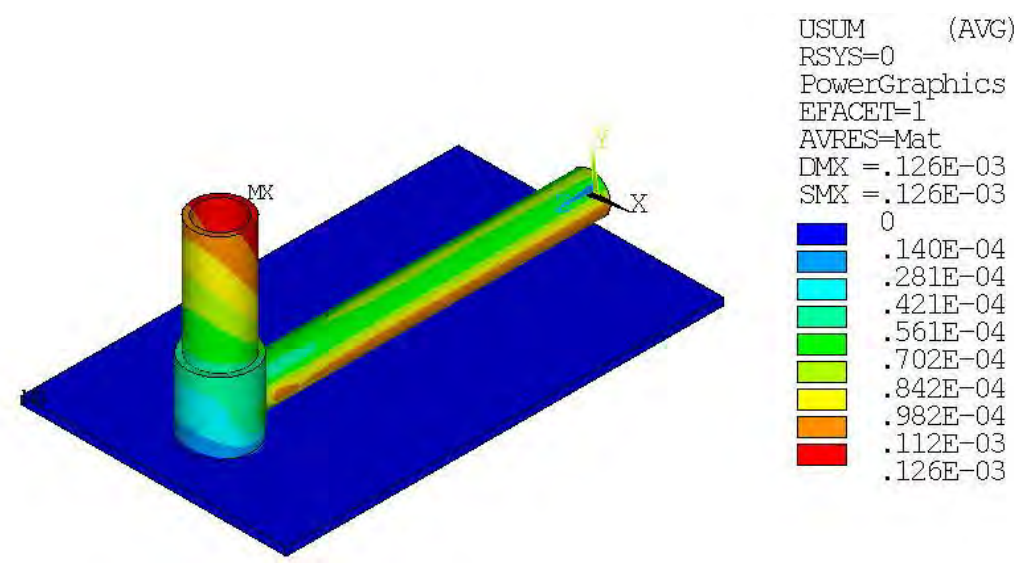

Figure 4. Total displacement nephogram of inverted siphon under case $3(\mathrm{~m})$

As can be seen from Fig .4, the maximal displacement of inverted siphon structure appears at the top of shaft-well, its maximum displacement is $0.126 \mathrm{~mm}$, displacement distribution is layered basically, this is because the displacement is mainly due to foundation settlement caused by dead weight, that is to say, inverted siphon has taken place in the downward whole displacement.

\section{CONCLUSION}

In conclusion, stress and deformation value of Tieluqiao inverted siphon is small, inverted siphon can satisfy the intensity and the rigidity requirement, its design scheme is economic, reasonable, safe and reliable.

\section{REFERENCE}

[1] Hui-Fang Xue,You Wang. Self-Vibration Characteristics of Plane Gate in Inverted Siphon Project C]. Advances in Intelligent Structure and Vibration Control.2012:62-66.

[2] Yan, Yibo,Liu, Guoqiang,Wang, Changde et al. Discharge Error Analysis of Check Gate Combined with Inverted Siphon in a
Canal Simulation System [C]. 2011 International Conference on Control, Automation and Systems Engineering. [v.1].2011:1-4.

[3] SL191-2008. Design Code for Hydraulic Concrete Structure[S]. China Water Conservancy and Hydropower Press, 2008.

[4] Wenliang Ma,Weifang Zou. Three-dimensional finite element analysis of trench-buried inverted siphon structure [C]. 2012 7th International Conference on System of Systems Engineering. $2012: 380-382$

[5] Lun-Yan Wang,Lei Guo. Analysis on Concrete's Measures for Qin river Inverted-Siphons in winter [C]. Proceedings of the third international conference on modelling and simulation. vol. 2, Modelling and simulation in engineering.2010:70-73.

[6] Xucheng Wang. Finite Element Method [M]. Tsinghua University Press, 2003.

[7] Bofang Zhu. Finite Element Method Principle and Application [M]. China Water Conservancy and Hydropower Press, 1998.

[8] Cheng Zibing,Wang Feng,Yan Wei et al. Experimental study on inverted siphon channel in South-to-North water diversion project [C]. Advances in hydraulic physical modeling and field investigation technology.2011:685-689.

[9] Jiaxuan Mai. Hydraulic Structures [M]. Tsinghua University Press, 2005.

[10] Huiying Li, Wenduo Tian, Haixin Yan. Inverted Siphons [M]. China Water Conservancy and Hydropower Press, 2006. 